\title{
RAIDERS OR SAVIORS? \\ THE EVIDENCE ON SIX \\ CONTROVERSIAL INVESTORS
}

\author{
by \\ Clifford G. Holderness \\ Dennis P. Sheehan \\ Horking Paper Series No. \\ MERC 84-06 \\ 1985
}

April, 1985

(Forthcoming in the Journal of Financial Economics)

Managerial Economics Research Center

Graduate School of Management

University of Rochester

Rochester, NY 14627 


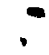




\title{
RAIDERS OR SAVIORS? \\ THE EVIDENCE ON SIX CONTROVERSIAL INVESTORS \\ by \\ Clifford G. Holderness \\ Dennis P. Sheehan
}

\begin{abstract}
Carl Icahn, Irwin Jacobs, Carl Lindner, David Murdock, Victor Posner, and the late Charles Bluhdorn are usually portrayed as corporate "raiders." The evidence here, however, shows that between 1977 and 1992 when it was first announced that they had purchased stock in a given firm, stock prices on average increased significantly. The investors' activities in target firms for the two years following the initial stock purchase are likewise inconsistent with "raiding." We discuss two hypotheses that are consistent with the evidence: first, these investors improve the management of target firms; second, they are systematically able to identify under-priced stocks.
\end{abstract}


. 
First Draft: November, 1983

Current Draft: April, 1985

\title{
RAIDERS OR SAVIORS?
}

\section{THE EVIDENCE ON SIX CONTROVERSLAL INVESTORS}

\author{
Clifford G. Holderness* \\ Dennis P. Sheehan*
}

\section{INTRODUCTION}

Of all the participants in the market for corporate control, few have been more controversial (at least in the public's eye) than Carl Icahn, Irwin Jacobs, Carl Lindner, David Murdock, Victor Posner, and the late Charles Bluhdorn (henceforth referred to as the "six investors" or simply as "the six"). 1 " These six investors have been characterized as everything from "a liar of the worst kind"리 to "(a) sharp-shooter ... (who) helps keep management on its toes"; $3 /$ from "no credit to the capitalist system"-4 to "an 'asset player' who has a nose for undervalued situations and guts to buy when many other people are scared." 1 /

But the most prevalent view is that the six are "corporate raiders" who reduce the wealth of their fellow stockholders. Thus, Carl Icahn is portrayed as a "notorious corporate opportunist' and a 'racketeer,' an unprincipled predator who will stop at nothing in his search for a quick buck."6/ To his critics Irwin Jacobs "is a corporate raider who has shown little talent for running the public companies he has

\footnotetext{
* Assistant Professor, University of Rochester, Graduate School of Management. We have benefited from the comments of Andrew Christie, Amor Gosfield, Michael Jensen, Stuart Klein, Wayne Mikkelson, Clifford Smith, Lee Wakeman, Jerold Warner, Jerold Zimmerman, and an anonymous referee. We would especially like to thank Harry DeAngelo for his generous assistance throughout our research. Finally, we would like to thank Hesna Genay and Amy Schlenker for research assistance and Michel Vetsuypens for computational assistance. This research has been funded by the Managerial Economics Research Center of the Graduate School of Management, University of Rochester.
} 
acquired."II When Charles Bluhdorn was CEO of Gulf \& Western it acquired the nickname Engulf \& Devour. - / Fellow stockholders brought suit against Carl Lindner alleging that he illegally borrowed corporate funds and then made unauthorized purchases of securities at "prices far above market value." $\underline{9 /}$

While all six have been viewed as corporate raiders, the most notorious raiding reputation undoubtedly belongs to Victor Posner. In fact, he "is rarely identified without the tag 'corporate raider"'니의 ; moreover, "few businessmen have suffered more abuse in recent years than Victor Posner."11/ To his numerous critics Posner has "all the talent of an accomplished raider: boldness, ferocity, tenacity and greed. He may not be a promising candidate for charitable work, but for the provision of loot his credentials are excellent." $\underline{12 /}$

Although such allegations are often levied against the six, there never is a precise definition of corporate raiding. One can, however, from news reports (and with a constructive imagination) outline several possible definitions of raiding, all having the common elernent of reducing the wealth of other stockholders. The most extreme form of raiding apparently centers around "looting" the corporate treasury. For example, following Victor Posner's acquisition of stock in Foremost-McKesson, a lawsuit was filed against him alleging that his goal was "to prey upon and defraud stockholders of a carefully chosen series of corporations by means of a corruptly conceived and maliciously executed strategy of corporate warfare." $13 /$ It was further alleged that Posner had "taken over and looted at least eight corporations in approximately as many years." $14 /$

Another perhaps less drastic definition of raiding is that the six use their corporate voting power to accord themselves "excessive" compensation and perquisites. This possibility was raised by some when in 1978 Victor Posner earned at 
least $\$ 1.5$ million in salary, bonus, and benefits from Sharon Steel Corporation, $\underline{15 /}$ and when Posner's daughter, who is a director of some of his companies, was provided with an apartment at corporate expense. $16 /$

One could even define raiding to encompass instances where firms repurchase, typically at a premium over the market price, only the shares held by the controversial investor, so-called "greenmail". Under this definition of raiding it is not even necessary for an investor to gain a voting majority to effectuate transfers from other stockholders. Dann and DeAngelo (1983) as well as Bradley and Wakeman (1983) present evidence that targeted repurchases by firm's tend to reduce the wealth of stockholders who are not offered the same opportunity. Moreover, there have been press reports of the six investors having their shares so repurchased. For example, Kaiser Steel Corporation repurchased shares held by Jrwin Jacobs at $\$ 52$ a share, while other Kaiser stockholders received only $\$ 40$ a share. $\underline{17 /}$

This paper uses market evidence to attempt to ascertain the role of these six investors. More specifically, we want to determine: (1) Does the evidence support the hypothesis that the six are corporate raiders who reduce the wealth of other stockholders? (2) If the evidence is inconsistent with the raiding hypothesis, what is the market role of the six? To answer these questions we measured the stock price changes associated with the first public announcements of stockholding by any of the six investors between 1977 and 1982 (inclusive). Stock price changes were measured for both the firms the six were buying into ("target firms") as well as the firms the six used to make those purchases ("filing firms"). No matter how corporate raiding might be defined, fundamentally it seems to imply that stock acquisitions by the raider ultimately reduce the wealth of other stockholders in target firms. The evidence uncovered by our inquiry, however, shows that on average 
stockholders of target firms earned statistically significant positive abnormal returns when it was first announced that one of these six controversial investors had purchased stock. The second part of our inquiry was to follow the investors' activities in the target firms for the two years following their initial stock purchases. The evidence from this inquiry is likewise inconsistent with the hypothesis that the six have been corporate raiders.

Thus, the empirical evidence from both parts of our inquiry is inconsistent with the raider image of the six investors. The empirical findings, on the other hand, fail to identify the precise role of the six. We do, however, discuss two hypotheses that are consistent with some if not all of the empirical findings: first, that the six improve the management of target firms; second, that the six consistently identify underpriced stocks. 
Page 5

\section{THE DATA}

\section{A. Initial 13(d)'s and Stock Price Changes}

Under the Security and Exchange Commission's (SEC) Regulation 13(d), individuals or companies must report to the SEC within ten days of acquiring any security in a publicly traded firm if after that acquisition the individual or company owns more than $5 \%$ of the outstanding class of security. $\underline{18 /}$ These initial 13(d)'s $19 /$ are available almost immediately in the SEC's public records room and are shortly thereafter published in the SEC News Digest. It is from the se filings that the public presumably first learns of new securities investments by anyone, including investments by the six individuals of interest to us.

To measure the stock market's response to the first announcement of initial stockholding by the six investors, we collected from the SEC News Digest for the six years 1977-1982 all initial 13(d)'s filed by any of the investors or filed by any company affiliated with one of them. The affiliated companies, which are listed in the Appendix, were identified by searching two computer-based information services, the Dow Jones Free Text Search and the ABI/INFORM Data Base. 20 / Together these services contain over 360,000 entries, including the text (1979 to present) of the Hall) Street Journal, Barron's, and the Dow Jones News Service, plus abstracts of articles (1971 to present) from more than 500 journals, including Business Owner, Business Week, Financial Analysts Journal, Forbes, Fortune, Institutional Investor, and Mergers and Acquisitions. In this manner we identified 35 companies that were publicly known to be affiliated with, if not controlled by, one of the six investors for at least some period between 1977 and 1982. To be sure, it is possible that any of the six investors might have had "hidden" interests in other companies that were used as vehicles to acquire stock. But because this study concerns the stock market's reaction to activities known to involve the six investors, no attempt was made to examine stock 
Page 6

acquisitions by "hidden" affiliates.

From the initial sample of 15513 (d)'s gathered from the SEC News Digest (see Table I for this data presented both by individual investor and for the six in aggregate), we eliminated target companies not listed on either the New York or American Stock Exchanges in order to use the CRSP computer file of daily stock prices. Target companies were also eliminated if there was insufficient stock return data before or after the event day, or if the company's stock did not trade during the event period. $\frac{21 /}{}$ The final sample of target firms used to measure the stock price changes associated with the first public announcement of stockholding by the six contains 99 observations: 5 for Icahn, 5 for Jacobs, 21 for Lindner, 10 for Murdock, 31 for Posner, and 27 for Bluhdorn (all occurring while he was Chief Executive Officer of Gulf \& Western).

We also measured the stock price changes of the firms filing these $13(d)$ 's. Starting with the target firm sample of 99 observations, we eliminated all observations when the filing firm was not listed on the New York or American Stock Exchanges, or when there was insufficient data surrounding the event date and during the event period. $22 /$ The final sample used to measure the stock price changes of the filing firms consists of 72 observations: 3 for Murdock, 45 for Posner, 23/ and 24 for Bluhdorn.

To compare the market's response to initial stockholding by any of the six with the market's response to initial stockholding by an "average" investor, we collected a random sample of 689 13(d)'s filed during 1977-1981. The random sample was generated by examining every tenth filing of an initial $13(d)$ as reported in the SEC News Digest. When that filing was by anyone other than one of the six investors (or by an affiliated company), it was included in the random sample, otherwise it was passed over. The sample used to measure the stock price changes of the random target firms has 155 observations. $\frac{24 /}{}$ The final sample of random filing firms consists of 30 
observations. The data for both the six investors and the random sample are summarized in Table 1.

\section{(Table I goes here)}

\section{B. Corporate Activities of the Six Investors In Target Firms After Initial Stock Purchases}

To further investigate how the six investors affect target firms, we tracked their activities in the target firms for the two years following an initial 13(d). This investigation had a number of components. From the SEC News Digest we determined how many amended 13(d)'s were filed by the six for each target firm. (Amended 13(d)'s must be filed with each $2 \%$ increase in the holdings of any security.) In addition, the Wall Street Journal Index and the Dow Jones Free Text Search were reviewed for three categories of corporate activity: First, we investigated how of ten the investor's shares were repurchased by the target firm. Second, it was determined how often the target firm was involved in a corporate reorganization, which includes mergers, takeovers, and going private transactions, whether the firm instigating that reorganization was affiliated with one of the six investors, and whether the reorganization was completed (all within the two year period). Finally, we searched for press reports that the six assumed an active role in the management of the target firm. 
Page 8

\section{EMPIRICAL FINDINGS}

\section{A. Market Reaction to the First Public Announcement of Stockholding by the Six Investors}

1. Methodology

The event study methodology used in this paper is well known. Thus, we provide only a brief overview here. $\frac{25 /}{}$ To adjust for systematic risk, the simple market model was estimated

$$
R_{i t}=\alpha_{i}+\beta_{i} R_{m t}+u_{i t}
$$

where $R_{i t}$ is the return to firm $i$ at time $t, R_{m t}$ is the equal weighted return to the market portfolio at time $t, u_{i t}$ is an independent and identically distributed random error term, and $\alpha_{i}, \beta_{i}$ are the unknown parameters to be estimated. These two parameters were estimated from a sample of approximately 200 trading days, from 300 days before the event (typically the filing of the 13(d)) through 100 days before the event. $26 /$ Using the estimated $\alpha_{i}$ and $\beta_{i}$, predicted returns for firm $i$ were then generated for forty days before and after the event day. Abnormal returns were accordingly calculated as the difference between the actual and the predicted returns:

$$
A R_{i t}=R_{i t}-\hat{\alpha}_{i}-\hat{B}_{i} R_{m t} .
$$

These abnormal returns were then averaged across events, that is, across the announcements of initial stock purchases, to form a portfolio abnormal return:

$$
\overline{A R}_{t}=\sum_{i=1} A R_{i t} / n
$$

where $n$, which is constant over all days in the event period, is the number of observations (see Table I). Finally, cumulative abnormal returns (CAR) were formed by summing the continuously compounded abnormal returns over the event period. 
The events being analyzed are the first public announcements of stockholding in a given target firm by any of the six investors. For the purposes of this study, day zero in event time ("event day") is defined as the earliest date on which an initial stock purchase (or a forthcoming purchase) was publicly revealed. In most instances this information was revealed by the filing of a $13(d)$ which was available to the public almost immediately upon receipt by the SEC. $27 /$ In approximately $10 \%$ of the cases, however, there was an announcement of an impending filing $\underline{28 /}$ on either the Dow' Jones News Wire or in the Wall Street Journal. Because under all of these scenarios, information of the stock purchase can be released when the market is closed, a twoday event day return is a better measure of the returns associated with the announcement. When day zero is either a 13(d) filing date or a Dow Jones News Wire date, the event day return is calculated from that day's return plus the next day's; for Wall Street Journal announcements, the event day return is that day's return plus the previous day's. Therefore, "event day" return refers to the sum of the continuously" compounded two-day return calculated for days $(0,+1)$ or $(0,-1)$, whichever is appropriate given how the information of the stock purchase was released to the market. For all other calculations of abnormal returns in this paper, single day returns are used.

A standard t-test is used to test for statistical significance of abnormal returns associated with the announcements of initial stock purchases. The sample variance of the average abnormal return over the event period $29 /$ was computed as:

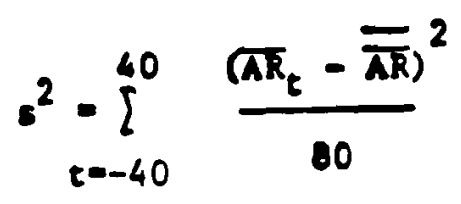

where

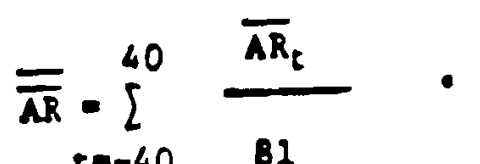


Under the null hypothesis of zero abnormal returns, the ratio $\overline{A R}_{t} / s$ is $t$ distributed with 80 degrees of freedom. The variance of the cumulative return was obtained by' summing the sample variance of the abnormal returns over the number of days contained in the cumulative return; a similar procedure was followed for the two-day event day returns.

\section{Target Firms' Stockholder Returns}

Average daily abnormal returns $(\overline{R R})$ and cumulative average daily abnormal returns (CAR) to stockholders in target firms where any of the six investors filed an initial 13(d) are presented in Table II and plotted in Figure 1. The frequency distributions of event day returns and CAR's for both the six and the random sample of initia! 13(d)'s are found in Figures $2 \mathrm{~A}$ and 2B.

(Table II, Figures $1,2 \mathrm{~A}$, and $2 \mathrm{~B}$ to go here.)

The most prominent finding in Table II is the positive abnormal return of $1.77 \%$ earned on average by stockholders in target firms on the day of and the day following the first public announcement of initial stockholding by one of the six investors. The t-statistics for selected periods from 40 days before to 40 days after the event day are also presented in Table II. The t-statistic for the event date is 3.7; the null hypothesis of a zero mean event day return can, therefore, be rejected at the .0I significance level. Interpretations of these and all empirical findings are delayed until Section IV.

Table II and Figure $I$ also indicate that on average stockholders in target firms realized wealth increases during the days immediately preceding the public announcements of initial stock purchases by the six investors. Stock price increases have been documented for the days preceding other corporate transactions, including mergers, tender offers, proxy contests, and going private reorganizations. As with these other corporate transactions, the stock price increases prior to the announcements suggest that the event day returns underestimate the wealth increases 
of stockholders. Accordingly, we measured the cumulative abnormal returns commencing forty days prior through forty days after the event day; we also measured the abnormal returns over the period from ten days before through the event day. Both findings are reported in Table $\mathrm{III}$ and confirm that announcements of initial stock purchases by the six investors are on average associated with wealth increases for target firms' stockholders. Finally, it should be noted that the downward drift in stockholder returns from the event day through the end of the event period is statistically insignificant.

(Table III goes here.)

The amount of the initial holdings of the six investors as a percent of the total number of shares of the target firm outstanding was reported in the SEC News Digest for 80 of the target firms in our final sample. Approximately $90 \%$ of the initial holdings were for less than $12 \%$, but the remaining decile ranged between $20 \%$ and $64 \%$. This information provided an opportunity to determine whether the size of the initial holding affected the magnitude of stock price changes for the target firms. Simple regressions of the event day return and the cumulative return for the eighty day event period on the percent of the initial holding, however, revealed almost no relationship between either of the dependent variables and the size of the initial holding.

A possible explanation for the increase in stock prices around the event date could be an increase in demand for the stock of the target firm. If the excess supply curve of the firm's stock is upward sloping, this new demand could only be met at higher prices. $\frac{30 /}{}$ Presumably the magnitude of the price increase would be positively: related to the size of the stock purchase. The evidence just cited indicates that if such a relation exists, it is quite weak (the size of the initial holding explained only 
about $5 \%$ of the variation in abnormal returns).

It should be noted, however, that our data do not allow a strong test of the effect of block size on price, because the dates of the actual stock purchases do not have to be reported to the SEC. It is possible, indeed even likely, that a substantial part of any acquisition plan by one of the six investors would have transpired before our event period. In that case our data would reveal almost nothing about whether the increased demand put upward pressure on stock prices.

With respect to the comparison of the six with the random sample, we found that a random $13(d)$ is on average likewise associated with a statistically significant increase in the stock price of target firms. The increase on the event day, however, is smaller for the random sample than it is for the six $(0.4 \% \mathrm{v} .1 .8 \%)$. To test the hypothesis that these two abnorinal returns were equal, a standard two-sample t-test was used. We treated the (two-day) announcement day returns as a set of independent drawings from populations that have equivalent variances $31 /$ and the same mean under the null hypothesis. The difference in means yielded a t-statistic of 2.2 , with a pvalue of .03 . The announcement day returns therefore appear to be statistically. distinguishable. Over the eighty-day event period, on the other hand, the CAR's are statistically similar for both groups $(6.7 \%$ for the six, $5.8 \%$ for the random sample). (See Figure 1 and Table III.)

Finally, because the six investors do not act as a group, for each of the individual investors we conducted the same empirical investigations as we did for the six collectively. Highlights of those findings are in Table Ill. As reported there, we found no statistically significant negative returns for any of the investors during any of the three periods studied. 


\section{Filing Firms' Stockholder Returns}

We also measured stock price changes for firms purchasing stock in other companies and thus filing a 13(d) ("filing firms"). These returns, however, need to be interpreted with caution. To the extent that a filing firm has a reputation for acquiring stock in other companies, the expected value, be it negative or positive, of stock acquisitions to filing firms will be incorporated in the stock price when the acquisition program first becomes known by the market. $\frac{32 /}{}$ New announcements of stock purchases will affect stock prices of filing firms only to the extent that it causes the market to revise its previous expectations. Jensen and Ruback (1983, p. 20) summarize additional difficulties in measuring returns to bidding firms involved in take-overs and mergers, difficulties that are also relevant for measuring returns to firms filing 13(d)'s. With these cautions in mind, returns to filing firms affiliated with one of the six investors are summarized in Table IV and plotted in Figure 3. Although the event day returns for the six are strongly positive, the CAR's are slightly negative. The downward drift in CAR's after the event date lacks statistical significance. Tabje IV and Figure 3 also contain findings for the random sample of filing firms as a benchmark to evaluate the findings on the six investors.

(Table IV and Figure 3 go here.)

\section{B. Activities of the Six Investors in Target Firms After Initial Stock Purchases}

\section{Summary of Activities in Target Firms}

Activities of the six investors in the target firms for the two years following an initial $13(d)$ are summarized in Table $V$.

(Table V goes here.)

It is difficult to generalize about the activities of the six investors in target firms, particularly given the small sample size of most of the categories of 
activities. A few points, however, are noteworthy. In keeping with the general impression received from the financial press, seldom are the six totally passive after their initial stock purchases. Typically, for instance, at least one amended 13(d) is filed. There are also differences among the six regarding their activities in target firms. For example, David Murdock's initial 13(d)'s have sometimes been a prelude to his takeover of the target firm. In contrast, although Lindner and Posner have also bought into firms before reorganizations, the reorganizations are more likely to have undertaken by a third party.

\section{Event Studies of Selected Activities In Target Firms}

To measure the market's reaction associated with various activities by the six investors in target firms, we divided the firms into four categories according to outcome: target firms that were successfully reorganized (whether by the investor or by a third party) within two years of the initial 13(d); those where a reorganization effort failed within the two years; those where the target firm repurchased at least some of the investors' shares, again within two years; and, finally, all other target firms where we had two years of observations following the initial 13(d). For the first three of these categories we measured event day abnormal returns to target firm stockholders associated with three types of events: the announcement of the initial stock purchase, "significant" intermediate events, and the final event. Significant intermediate events are those instances (in the authors' opinion) in which the investor revealed significant information about his future intention with respect to the target firm, or when the target firm's management revealed significant information on how they planned to respond to the investor. A representative intermediate event was January 21, 1980 when it was announced that Carl Icahn asked the President of Saxon Industries to either repurchase his shares or face a proxy fight. The final event is 
defined as: the day on which the target firm's board announced its approval of a reorganization (for the successful reorganization category); or the day on which the reorganization offer was publicly withdrawn (for unsuccessful reorganizations); or the day on which the target firm announced that it would repurchase the investor's shares (for repurchases).

To further investigate the effect of these follow-up activities by the six investors, we calculated a measure of the overall or "total" return to stockholders in target firms due to the controversial investor's stockholding. This is similar to the procedure Mikkelson and Ruback (1984) used when studying corporate investments in other firms. The initial and final events are calculated (as earlier in the paper) as single events. $33 /$ Calculation of the "intermediate" and "fina!" events is, however, slightly more complicated. For the interinediate category, we summed the abnormal returns for all intermediate events for a particular firm. We then averaged these results over all firms in the sample (where we had at least one intermediate event) to obtain an average firm effect. To find the overall effect of the investor's association with a given target firm, we again summed all events (that is, the initial event, all intermediate events, and the final event) to obtain the "total" return for a particular firm. These firm returns were then averaged across all firms to yield the "total" average abnormal return associated with each of the three categories of outcomes (successful reorganization, unsuccessful reorganizations, and repurchase).

Table VI contains the event day abnormal stock price changes for target firms and relevant $t$-statistics associated with the initial stock purchase, intermediate events, and the final event as well as the summation of these events by category of outcome. The calculation of standard errors for these abnormal returns was done exactly as previously in the paper. The sample variance of the event period average abnormal returns was found and was then used to deflate the return for any day, thereby yielding a t-statistic. 
(Table VI goes here.)

When the entire involvement of the controversial investor in the target firm is examined in this way, several interesting observations are revealed. For each of the three categories of outcome, the total returns are positive. Moreover, for successful reorganizations and for repurchases the total return is significant at the .10 level. Once the initial purchase, intermediate events, and the repurchase are considered in aggregate, even investments that conclude with so-called "greenmail" are associated with statistically significant wealth increases for the target firm's stockholders. 


\section{INTERPRETATION OF THE EMPIRICAL EVIDENCE}

\section{A. Introduction: Three Hypotheses on the Six lnvestors}

We are now prepared to interpret the empirical evidence of Section III in light of three alternative, but not necessarily mutually inconsistent, hypotheses on the market role of the six investors. Briefly the three hypotheses are:

Raiding Hypothesis: The six investors purchase stock and then to the detriment of other stockholders "raid" target firms by transferring corporate assets to themselves.

Improved Management Hypothesis: The six help improve the management of target firms.

Superior Security Analyst Hypothesis: The six investors either possess non-public information on target firms or have skills at evaluating publicly-a vailable information on those firms. In either event, the six are able to identify and then purchase underpriced stocks.

\section{B. Raiding Hypothesis}

As explained earlier, the most prelevant view (at least within the financial press) is that the six investors are corporate raiders who, in some unspecified manner, expropriate corporate assets to the detriment of other stockholders. Before testing this hypothesis against the empirical evidence in Section III, it should be noted that the raiding hypothesis in general is logically flawed. As Bradley (1980) explains, once it becomes possible that someone is attempting to acquire $51 \%$ of a target firm's stock in order to raid it (in theory, leaving the owners of the other $49 \%$ of the firm with worthless stock), other investors should start acquiring the stock in order to be the first to gain voting control and thus be the one who is able to raid the target. $\frac{34 /}{\text { These }}$ entrants in the market for control will "bid up the price for $51 \%$ of the target to the market value of $100 \%$ of the firm's securities". $35 /$ In other words, "competition in the market for corporate control theoretically precludes corporate raiding strategies from being a positive net present value project." $36 /$ This argument that corporate raiding is 
precluded by the market for corporate control is consistent with the positive abnormal returns earned on average by stockholders in firms that are taken over,, $37 /$ merged, $38 /$ taken private,,$\frac{39 /}{}$ or are the objects of a "toehold" acquisition of at least $5 \%$ of its stock. $\underline{40 /}$

The empirical evidence on the six investors reported in Section III is likewise inconsistent with the raiding hypothesis. If the six investors in fact systematically reduced the wealth of other stockholders in target firms through corporate raidiñ, one would anticipate negative stock price changes associated with the first public announcement of stockholding by any of the six. These negative stock price changes would reflect the anticipation of market participants that the six investors would in the future transfer corporate assets to themselves or perhaps that those transfers had already been effectuated. But the initial stock price changes in target firms associated with the first public announcement of stockholding by the six are on average positive. When the six are viewed collectively, one finds on average statistically significant positive returns to stockholders of target firms over the ten days preceding and the day following the 13(d) filing, for the event day and, over the

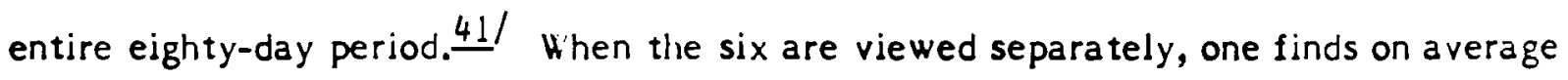
no negative returns that are significant at the .05 level for any of the six investors over the ten days preceding and the day following the 13(d), for the event day, and over the eighty-day event period. In short, it is difficult to see how the six investors, at least on average, harm stockholders in target firms.

The empirical evidence on the random sample of 13(d)'s provides additiona! evidence against the raiding hypothesis. The six investors are associated with target firm event day returns that are statistically significantly larger than target firm returns associated with filings by random investors $(1.8 \%$ for the six, $0.4 \%$ for the 
random sample). Over the entire event period, the wealth increases associated with the six investors are statistically indistinguishable from those associated with random investors ( $6.7 \%$ for the six, $5.8 \%$ for the random sample). Hence, from the perspective of a stockholder in a target firm, the six investors are, at least from some perspectives, more desirable -- in the sense of being associated with larger wealth increases -- than are other, apparently less controversial investors.

Additional empirical evidence inconsistent with the raiding hypothesis comes from reviewing the activities of the six investors in target firms after filing an initial 13(d). No matter what eventually happens to the target firm within two years -whether it reorganized, a reorganization fails, the controversial investors' shares are repurchased, or nothing happens -- target firm stockholders, on average, earn positive returns.

Of particular relevance for the raiding hypothesis are the empirical findings on targeted repurchases. Like other studies, we found that the announcements of targeted repurchases are on average associated with negative stock price changes for the firms making the repurchases. $\frac{42 /}{}$ However, the initial stock purchases that eventually led to those repurchases were on average associated with positive stock price changes $(4.1 \%, t=3.0)$. Once the relevant initial stock purchases, significant intermediate events, and the repurchase itself are considered in aggregate, the total returns to target firm stockholders associated with investments in their firm by one of the six investors are both positive and significant. These findings on total returns are similar to those of Mikkelson and Ruback (1984) who studied corporate purchases of stock in general over the period 1978-80. With their larger and different sample, they too found that the aggregrate of the returns associated with the initial purchase, intermediate events, and the repurchase were positive $(2.0 \%)$ and statistically significant $(t=3.4)$. 


\section{Improved Management Hypothesis}

The improved management hypothesis, in direct contrast with the raiding hypothesis, holds that the six investors help bring about management changes that increase the target firm's expected net cash flows and hence increase its value. Target firm management changes could result from either a change in corporate personnel -- a new CEO, for example -- or from a change in corporate policy -- for example, a decision to abandon a previously announced acquisition. Moreover, these management changes could either be instituted directly by the investor himself or be bought about by his support of another individual's proposal. An example of personal involvement in management occurred after David Murdock purchased stock in Cannon Mills Company and then

moved quickly to cut costs at Cannon, which he says had "archaic" management. He fired dozens of front-office employees one Friday on a half-hour's notice, laid off an estimated 2,000 millworkers, and warned the rest in a vicieotaped speech to work harder or lose their jobs 43 l'

On the other hand, when Irwin Jacobs bought stock in Walt Disney Productions he did not become publicly involved in mangement as such, but he did announce his opposition to a planned acquisition which had already been opposed by several other major Disney stockholders and by some directors. $\frac{44 /}{}$

Perhaps the strongest empirical evidence for the improved management hypothesis comes from the positive abnormal returns to stockholders in target firms associated with the first public announcement of stockholding by one of the six investors. These positive returns are consistent with the hypothesis that market participants believe that on average the six will improve the management of target firms and thereby increase net cash flows.

Additional empirical evidence consistent with the improved management hypothesis comes from the activities of the six investors following their initial stock 
purchases. If the six were associated with management changes, then one would anticipate follow-up activities after their initial stock purchases. In other words, they should not be "passive" investors. This is consistent with the empirical evidence. In only ten target firms out of seventy-three was there no public indication of any activity during the two years following an initial stock purchase. Moreover, in ten (again, out of seventy-three) target firms, one of the investors assumed a direct and publicly-visible management role. In six other cases one of the investors attempted to reorganize a target firm, while in thirteen other instances a third party attempted the reorganization after one of the six became a stockholder. Overall, thirteen target firms (out of seventy-three) were successfully reorganized within the two years following an initial stock purchase by one of the investors.

Management changes per se will not necessarily constitute improvements in the sense of increasing a target firm's expected net cash flows. The event studies on the follow-up activities, however, are consistent with the hypothesis that the managernent changes are in fact improvements. Successful reorganizations, which could be a prelude to the introduction of a new management team, $\underline{45 /}$ are associated on average with the largest wealth gains (measured as total announcement day returns) for target firms' stockholders $(13.0 \%, t=3.1)$. On the other hand, when it was announced that a reorganization effort was withdrawn, target firm stockholders suffered wealth losses $(-3.4 \%, t=-1.9)$ perhaps because management changes proposed by the investor and anticipated by the market had been rejected. Lastly, even the twelve targeted repurchases of the investors' share could be consistent with the improved management hypothesis if the initial purchase and the subsequent repurchase increased the scrutiny of the target firm's management. This scrutiny, in turn, could have resulted in more effective monitoring of management or even to an attempted reorganization. 
Thus, the empirical evidence is consistent with the hypothesis that the six are associated with improved management of target firms. But what are the implications of the empirical evidence for filing firms? In particular, do stockholders of firms filing 13(d)'s suffer wealth losses perhaps because of diseconomies of scale in management caused by these stock investments? The empirical evidence is inconsistent with this view. For filing firms affiliated with the six investors, statistically significant negative returns were on average not observed over the eighty-day event period. Indeed, the event day abnormal returns are both positive and significant $(1.7 \%, t=3.0)$. In contrast, the event day returns for a random filing firm are positive but insignificant $(0.4 \%, t=0.8)$.

\section{Superior Security Analyst Hypothesis}

The superior security analyst hypothesis holds that the six investors systematically purchase under-priced stocks. These stock purchases could be based either on non-public information about target firms possessed by the six or on skills the six have in interpreting publicly-available information about target firms.

The positive abnormal returns to stockholders in target firms associated with the first public announcements of stockholding by the six are consistent with either version of this hypothesis. Moreover, it is possible that some investors systematically possess more valuable non-public information than do others or have greater skills at interpreting publicly-available information on target firms. If the market is aware of this, then this hypothesis could explain the observed differences in initial stock price changes depending on the identity of the individual filing the 13(d).

Other empirical findings reported in Section lll, most notably the direct involvement of the six investors in management and the targeted repurchases of their shares, can not be explained by the superior security analyst hypothesis. The superior 
security analyst hypothesis has relevance only for stock purchases and does not address follow-up activities in target firms. It should be noted, however, that the evidence on the follow-up activities is not inconsistent with the superior security analyst hypothesis. Indeed, it is possible given all of the empirical evidence reported in Section III that the improved management hypothesis and the superior security analyst hypothesis simultaneously explain the market roles of these six investors. In other words, these two hypotheses are not mutually inconsistent. 


\section{v. CONCLUSION}

The empirical evidence reported in this paper lends no support to the corporate raider image of Carl lcahn, Irwin Jacobs, Carl Lindner, David Murdock, Victor Posner, and the late Charles Bluhdorn. To the contrary, the empirical evidence shows that announcements of initial stock purchases by these six investors were on average associated with statistically significant increases in the wealth of target firms' stockholders. Moreover, on average these increases, at least for the announcement day, exceeded the increases associated with initial stock purchases by random (typically less controversial) investors. The activities of the six in target firms after they file an initial $13(d)$ also provide no support for the raiding hypothesis. Even when the controversial investors' shares were ultimately repurchased by the target firm (socalled "greenmail"), target firms' stockholders on average experienced statistically" significant wealth increases when the investor's entire tenure from the initial stock purchase through the repurchase as a stockholder is examined.

While the empirical evidence is inconsistent with raiding hypothesis, the precise market role of the six is less clear. One reasonable interpretation of the evidence is that the six investors are associated with management changes that increase the value of corporate assets. Although our investigation of the activities of the six in target firms sheds some light on these management changes, more research is needed to identify their precise nature, and to ascertain whether the investors helped cause these changes or whether they merely anticipated them. Additional research is also needed to see to what extent, if any, the initial abnormal returns resulted because the investors have skills at identifying under-priced stocks. Finally, additional research is 
needed to answer what is arguably the biggest mystery uncovered by our investigations: Given that the six investors are on average associated with increases in the wealth of other stockholders, how did they ever obtain the label of corporate raider, and why has that label persisted? 


\section{Footnotes}

1/ Although these investors do not act as a group, all six are studied here because they are of ten lumped together in the financial press as corporate raiders.

2//Fortune, September 19, 1983, p. 160 (a former business partner describing Irwin Jacobs).

3/Fortune, September 19, 1983, p. 164 (describing Irwin Jacobs).

4/Forbes, October 29, 1979, p. 36 (describing Victor Posner).

5/ Fortune, January 1977, p. 138 (describing Carl Lindner).

6/Institutional Investor, October 1982, p. 147.

I/ Wall Street Journal, October 27, 1982, p. 35.

8/Forbes, March 15, 1982, p. 31.

9/Wall Street Journal, January 9, 1980, p.1.

10/ New York Times, February 26, 1984, P. 6F.

11/ Barron's, November 19, 1979, P. 55

12/ Barron's, November 19, 1979, p. 55.

$13 /$ Quoted in the Wall Street Journal, June 23, 1981, p.1

$14 /$ Wall Street Journal, June 23, 1981, p. 1.

$\underline{15 /}$ Forbes, October 29, 1979, P. 34.

16/ Barron's Novem ber 19, 1979, p. 5.

$\underline{17 /}$ Wall Street Journal, October 28, 1983, p. 6.

$18 /$ Securities are broadly defined in the regulations to include bonds and stocks (both voting and non-voting). 
$19 /$ Subsequent $13(d)$ 's must be filed with each $2 \%$ increase in the holdings of any security. Unless otherwise specified, references in this paper to $13(d)$ 's are to initia! filings.

20/The computer searches were also used to double-check the SEC News Digest for announcements of 13 (d) filings and to search for expressions of intent by any of the six investors to acquire securities.

21/More precisely, target companies were eliminated when the CRSP file did not have 300 daily returns before the event date and 40 daily returns af ter the event date, which is typically the day when the $13(d)$ was filed at the SEC. For a more precise identification of the event date, see page 9. In addition, firms whose stock did not trade every day during the event period ( 40 days on each side of the event date) were also eliminated.

$\underline{22} /$ Filing companies were also eliminated following the same criteria used to eliminate target companies. See note 21 .

23/There are many observations for Posner because he of ten used multiple companies to buy stock in a single target firm. This was not true of the other investors.

$\underline{24}$ /For both the six investors and the random sample, we replicated the analysis after eliminating all target firms mentioned for any reason in the Wall Street Journal from three days before to three days after the event day. Because the results from these reduced samples were similar to the results reported here, the findings from the reduced samples are not reported.

25/ For an overview of event study methodology, see Brown and Warner (1985); Schwert (1981).

26/ The actual number of observations in the estimation period varies from 201 to 189 due to the lack of trading of certain securities on some days. If a security did not trade on a particular day, that day was simply passed over for both $R_{i t}$ and $R_{m}$.

27/Filing dates are published in the SEC News Digest shortly after the filing.

28/ Neither of these news services appears to cover 13(d) filings systematically. For example, most of the filings by the six investors were covered while few of the random sample of filings were reported. 
29/ An alternative approach would be to exclude the day being tested from the calculation of the variance of the event period excess returns. If there are variance increasing events occuring during the event period, such a procedure would tend to decrease the estimated variance, leading to larger t-statistics.

30/For more detailed discussions of this issue, see Scholes (1972); Mikkelson and Partch (1985); Holthausen, Leftwich, and Mayers (1984).

31/ An F-test on the variances could not reject the hypothesis of equality.

32/ See Malatesta (1983); Schipper \& Thompson (1983).

33/ The only difference with the earlier event study of the initial announcements of stockholding is that here firms were not eliminated from the sample if they did not trade on all days during the event period. Instead, all available returns were used and the denominator used in the averaging was adjusted according to how many firms were used to form the average for that particular day.

34 / Crucial to this argument is that parties must publicly notify the SEC pursuant to regulation 13 (d).

35/ Bradley (1980), p. 356 .

36/ Bradley (1980), p. 356 .

37/ Jensen \& Ruback (1983), pp. 10-16.

38/ Jensen \& Ruback (1983).

39/ DeAngelo, DeAngelo \& Rice (1984).

40/Mikkelson \& Ruback (1984); Harris \& Risk (1983); Madden (1981).

41/ While there are negative returns for some target firms, overall these negative returns are out-weighed by the positive returns for other target firms.

42/ As reported in Table VI, announcements of repurchases were associated with returns of $-1.3 \%, t=-1.5$. Equivalent results on the announcement of repurchases from other more general studies are as follows: Dann and DeAngelo (1983) $(-1.8 \%, t=-3.6)$; Bradley and Wakeman (1983) $(-1.2 \%, t=-3.3)$; Mikkelson and Ruback (1984) $(-1.7 \%, t=$ -4.2)

43/ Wall Street Journal, March 2, 1983, p.1. 
44/Wall Street Journal, July 30, 1984, p.4.

45/ Jensen and Ruback (1983) suggest this possibility. 


\section{APPENDIX}

\section{AFFILIATED COMPANIES}

As explained in Section II, computer-based information services were used to identify which companies were perceived by the public to have been affiliated with any of the six investors for some period between 1977 and 1982. The results of these searches are listed below. When reviewing the SEC News Digest, we gathered all initial $13(\mathrm{~d})$ 's filed by the six investors or filed by any company listed below when it was affiliated with the pertinent investor:

\section{CARL ICAHN}

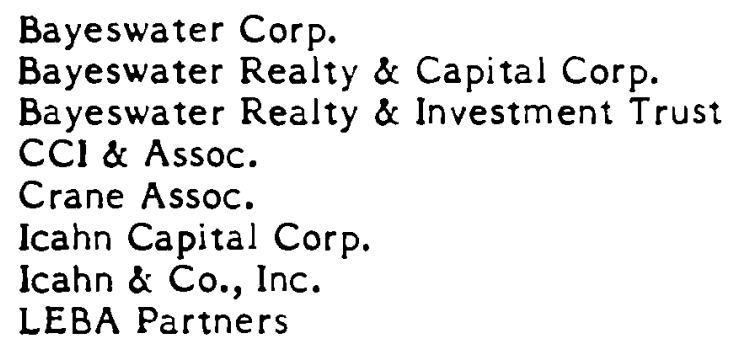

\section{IRWIN L. JACOBS}

Arctic Enterprises Jacobs Industries, Inc. Minstar Inc.

\section{CARL LINDNER}

American Financial Corporation

Circle K Corp.

Fairmont Food Co.

Provident Bancorp, Inc. 


\section{DAVID MURDOCK}

Cannon Mills Co.

International Mining Corp.

Murdock Investment Corp.

Occidental Petroleum

Pacific Holding Corp.

PAGO Mining Ltd.

PATO Consolidated Gold Dredging, Ltd.

\section{VICTOR POSNER}

APL Corp.

Birdsboro Corp.

Chesapeake Insurance Co. Ltd.

City Investing Co.

DWG Corp.

Insurance \& Risk Management, Inc.

NVF Corp.

Pennsylvania Engineering Corp.

Security Management Corp.

Sharon Steel Corp.

Southeastern Public Service Corp.

Summit Systems Inc.

\section{CHARLES BLUHDORN}

Gulf \& Western Industries, Inc. 


\section{REFERENCES}

Bradley, Michael, 1980, Interfirm tender offers and the market for corporate control, Journal of Business 53, 345-376.

Bradley, Michael and L. Macdonald Wakeman, 1983, The wealth effects of targeted share repurchases, Journal of Financial Economics 11, 301-328.

Brown, Stephen and Jerold B. Warner, 1985, Using daily stock returns in event studies, forthcoming in Journal of Financial Economics.

Dann, Larry Y. and Harry DeAngelo, 1983, Standstill agreements, privately negotiated stock repurchases, and the market for corporate control, Journal of Financial Economics 11, 275-300.

DeAngelo, Harry, Linda DeAngelo, and Edward M. Rice, 1984, Going private: Minority freezeouts and stockholder wealth, Journal of Law and Economics 27, 367-401.

Harris, R. S. and J. L. Risk, 1983, Toehold acquisitions in U. S. corporations: An examination of stock returns, unpublished manuscript (University of North Carolina at Chapel Hill).

Holthausen, Robert, Richard Leftwich, and David Mayers, 1984, The effect of large block transactions on security prices: A cross-sectional analysis, unpublished manuscript (University of Chicago).

Jensen, Michael C. and Richard S. Ruback, 1983, The market for corporate control: The scientific evidence, Journal of Financial Economics 11, 5-50.

Madden, Gerald P., 1981, Potential corporate takeovers and market efficiency: A note, Journal of Finance 36, 1191-1197.

Malatesta, Paul H., 1983, The wealth effect of merger activity and the objective functions of merging firms, Journal of Financial Economics 11, 155-181.

Mikkelson, Wayne H. and M. Megan Partch, 1985, Stock price effects and costs of secondary distributions, forthcoming in Journal of Financial Economics.

Mikkelson, Wayne H. and Richard S. Ruback, 1984, Corporate investments in common stock, unpublished manuscript (Massachusetts Institute of Technology).

Schipper, Katherine and Rex Thompson, 1983, Evidence on the capitalized value of merger activity for acquiring firms, Journal of Financial Economics 11, 85-119.

Scholes, Myron, 1972, The market for securities: Substitution versus price pressure and the effects of information on share prices, Journal of Business 45, 179-211.

Schwert, G. William, 1981, Using financial data to measure the effects of regulation, Journal of Law and Economics 24, 121-158. 
Number of linitial 13(d)'s Filed by the Six Investors

or By Affiliated Coinpunies During the Period 1977-1982 and

a Randuill Salnple of Initial 13(d)'s Froun the Period 1977-1981.

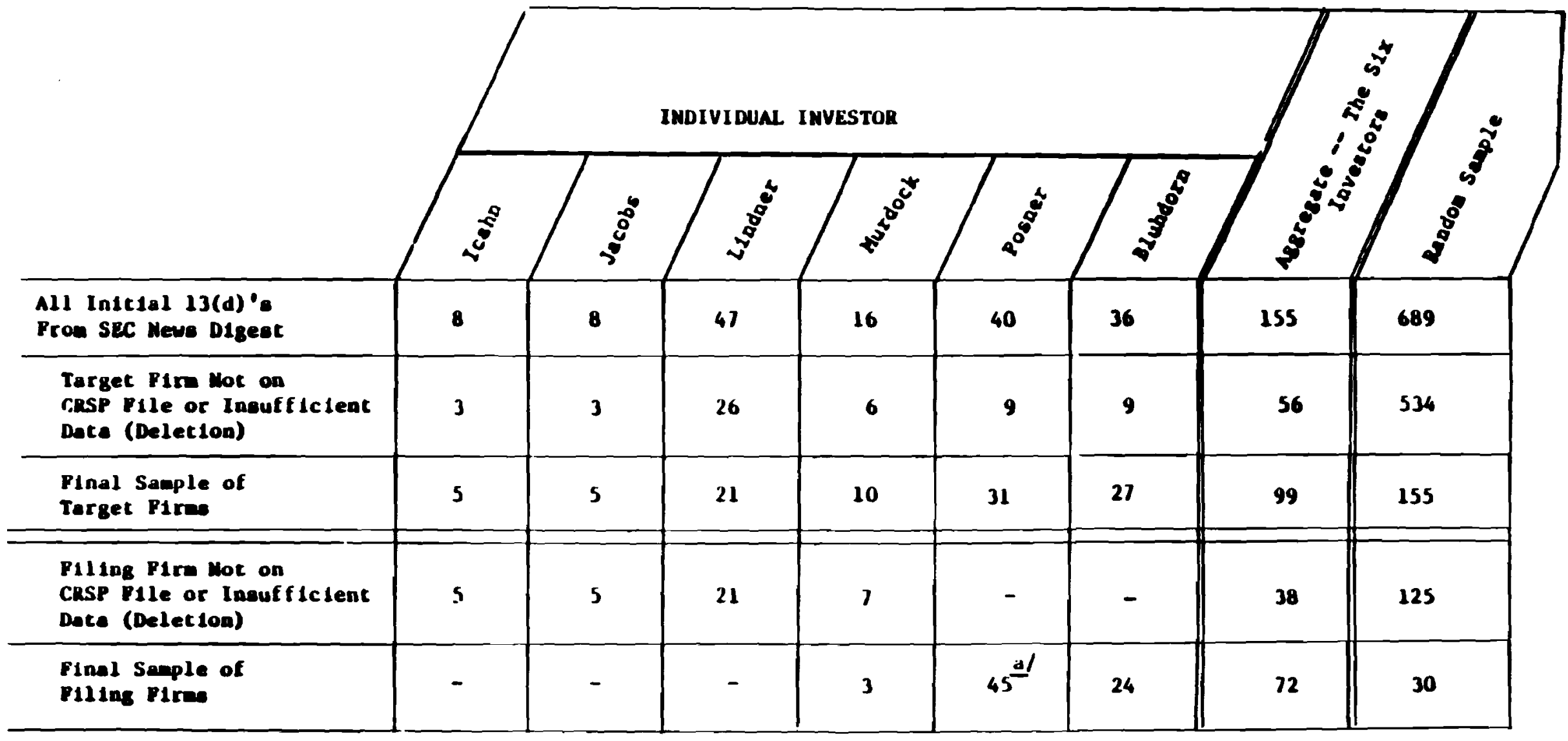

I/There are ininy ubservations for Posner because he often used inultiple companies to buy stock in a single target firm. This was nut true of the other investors. 
TABLE II

Average Daily Abnormal Returns and Cumulative Average Daily Abnormal Returns for Target Firms From Forty Days Before Through Forty Days After

The First Public Announcement of Stockholding By Any of the Six lnvestors, 1977-1982.

$$
\text { ( } n=99)
$$

Trading Day

$\begin{array}{cc}\text { Average Daily } & \text { t-Statistic } \\ \text { Return } & \text { Average } \\ & \text { Daily } \\ & \text { Return }\end{array}$

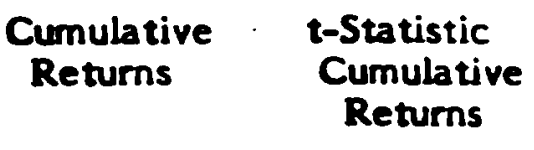

\begin{tabular}{|c|c|c|c|c|}
\hline-40 & 0.49 & 1.4 & 0.49 & 1.4 \\
\hline-30 & -0.04 & -0.1 & 1.18 & 1.0 \\
\hline-20 & 0.31 & 0.9 & 1.53 & 1.0 \\
\hline $\begin{array}{l}-15 \\
-14 \\
-13 \\
-12 \\
-11 \\
-10 \\
-9 \\
-8 \\
-7 \\
-6 \\
-5 \\
-4 \\
-3 \\
-2\end{array}$ & $\begin{array}{c}0.28 \\
0.28 \\
0.46 \\
0.31 \\
0.02 \\
0.17 \\
-0.07 \\
0.37 \\
0.77 \\
1.16 \\
0.43 \\
0.95 \\
0.17 \\
0.23\end{array}$ & $\begin{array}{c}0.8 \\
0.8 \\
1.4 \\
0.9 \\
0.1 \\
0.5 \\
-0.2 \\
1.1 \\
2.3 \\
3.4 \\
1.3 \\
2.8 \\
0.5 \\
0.7\end{array}$ & $\begin{array}{l}1.93 \\
2.21 \\
2.67 \\
2.98 \\
3.00 \\
3.17 \\
3.10 \\
3.47 \\
4.23 \\
5.39 \\
5.82 \\
6.77 \\
6.94 \\
7.17\end{array}$ & $\begin{array}{l}1.1 \\
1.3 \\
1.5 \\
1.6 \\
1.6 \\
1.7 \\
1.6 \\
1.8 \\
2.1 \\
2.7 \\
2.9 \\
3.3 \\
3.3 \\
3.4\end{array}$ \\
\hline 0 & 1.77 & 3.7 & 8.92 & 4.2 \\
\hline $\begin{array}{c}2 \\
3 \\
4 \\
5 \\
6 \\
7 \\
8 \\
9 \\
10 \\
11 \\
12 \\
13 \\
14 \\
15\end{array}$ & $\begin{array}{c}0.14 \\
0.63 \\
0.00 \\
0.41 \\
-0.33 \\
0.19 \\
-0.47 \\
0.32 \\
-0.32 \\
-0.19 \\
0.13 \\
-0.25 \\
0.04 \\
-0.21\end{array}$ & $\begin{array}{c}0.4 \\
1.8 \\
0.0 \\
1.2 \\
-1.0 \\
0.6 \\
-1.4 \\
0.9 \\
-1.0 \\
-0.6 \\
0.4 \\
-0.7 \\
0.1 \\
-0.6\end{array}$ & $\begin{array}{c}9.06 \\
9.69 \\
9.69 \\
10.10 \\
9.76 \\
9.95 \\
9.48 \\
9.79 \\
9.47 \\
9.28 \\
9.40 \\
9.15 \\
9.20 \\
8.98\end{array}$ & $\begin{array}{l}4.2 \\
4.4 \\
4.4 \\
4.5 \\
4.3 \\
4.3 \\
4.1 \\
4.2 \\
4.0 \\
3.9 \\
3.9 \\
3.7 \\
3.7 \\
3.6\end{array}$ \\
\hline 20 & 0.17 & 0.5 & 9.04 & 3.5 \\
\hline 30 & -0.10 & -0.3 & 8.53 & 3.0 \\
\hline 40 & -0.31 & -0.9 & 6.73 & 2.2 \\
\hline
\end{tabular}




\section{FIGURE 1}

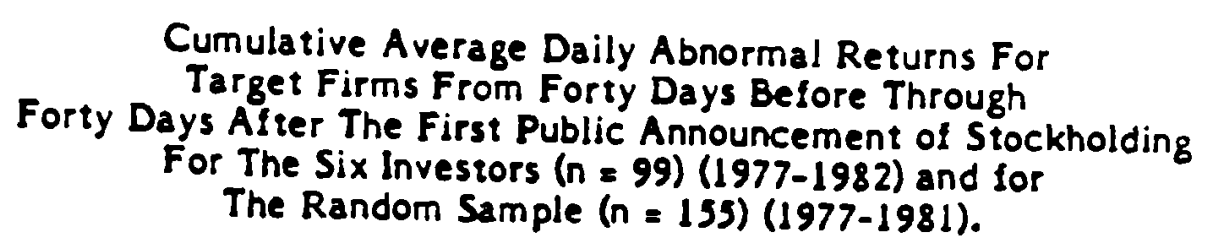

$\sum_{\underline{L}}^{n}$

岕

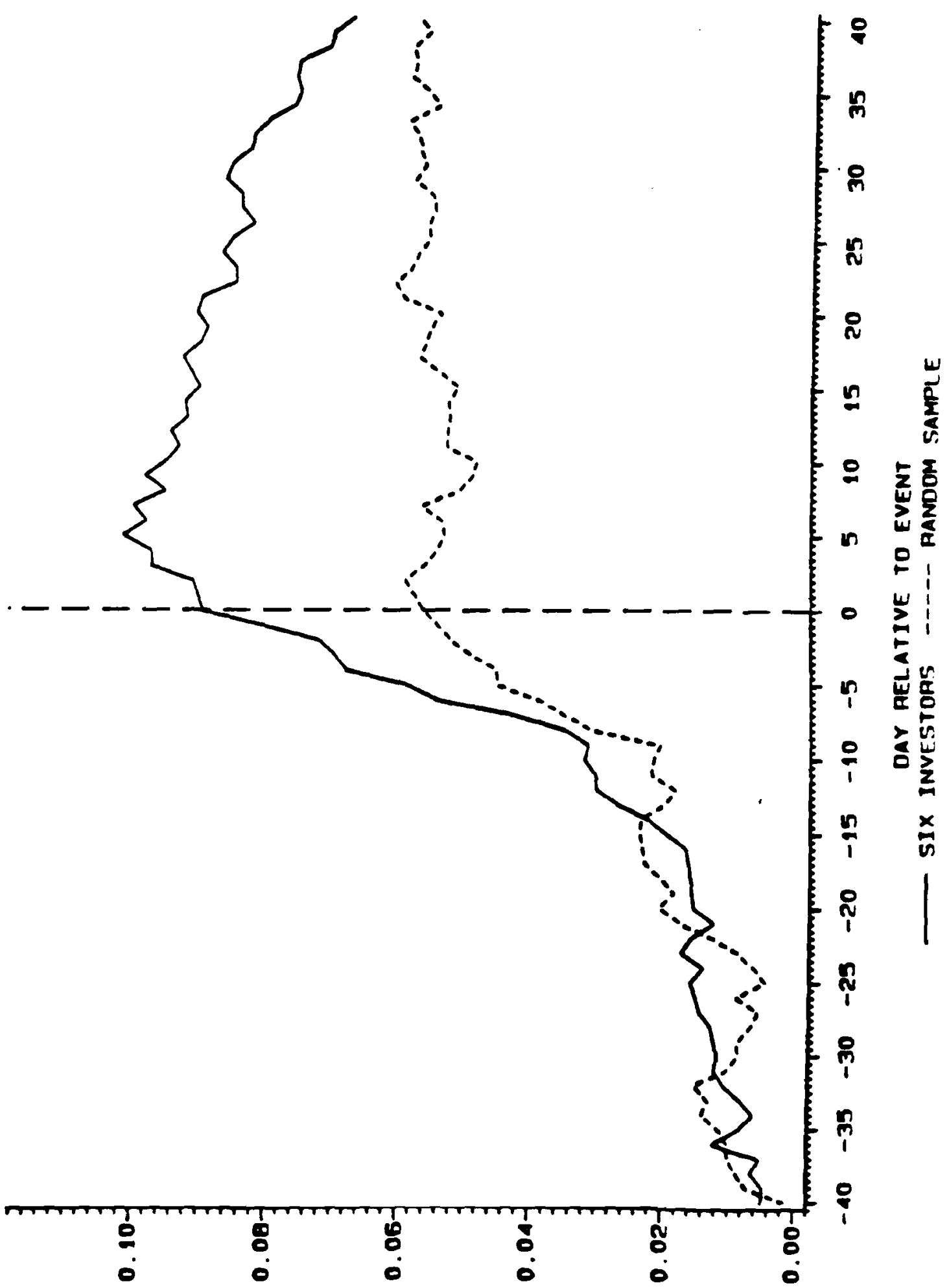

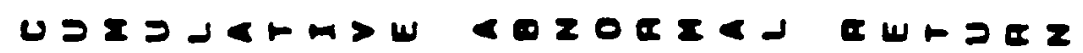




\section{FICURE 2A}

Frequency Distribution of the Two Day

Abnormal Returns for Target Firms at the First Public Announcement of Stockholding by the Six Investors

$(n=99)(1977-1982)$ and for the Random Sample

$(n=155)(1977-1981)$.

\section{DISTRIBUTION OF EVENT DAY RETURNS}

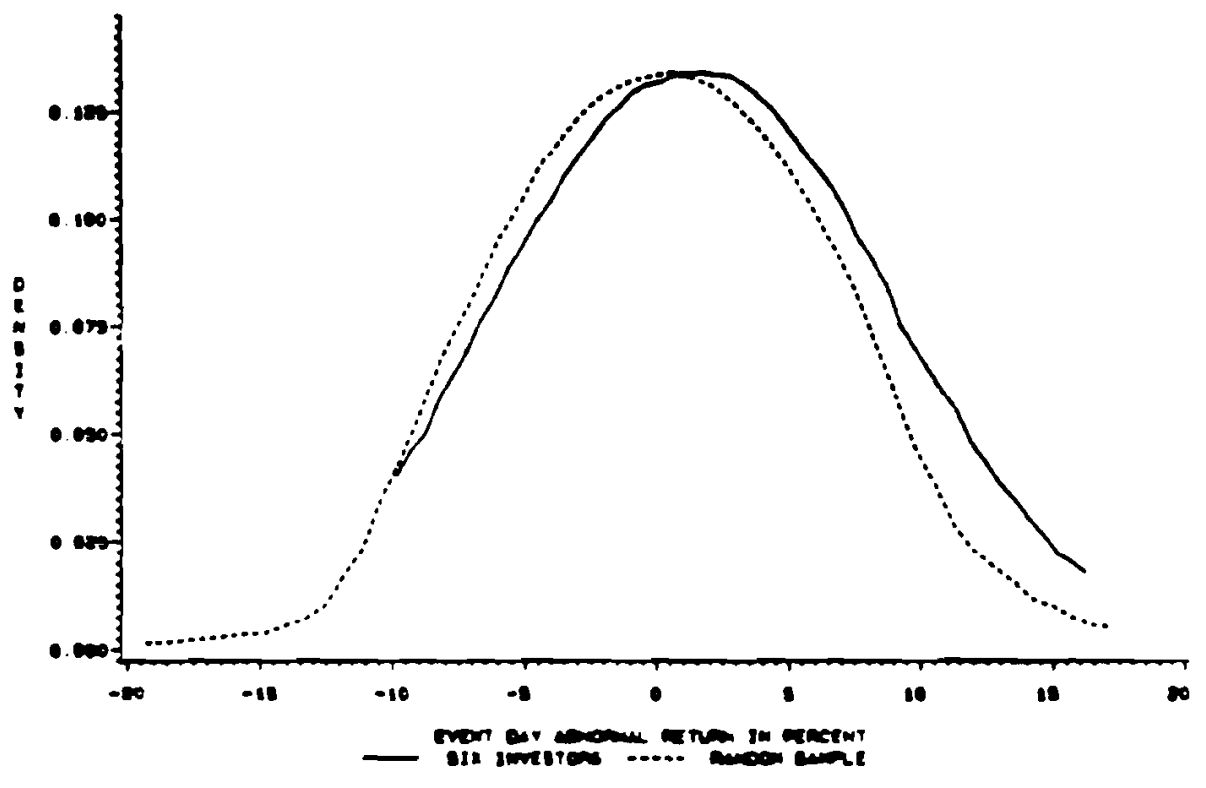

FIGURE 2B

Frequency Distribution of Cumulative Average Daily Abnormal Returns to Target Firms From Forty Days Before Through Forty Days After the First Public Announcement of Stockholding for Both the Six Investors $(n=99)(1977-1982)$ and for the Random Sample $(n=155)(1977-1981)$.

\section{DISTRIBUTION OF CUMULATIVE RETURNS}

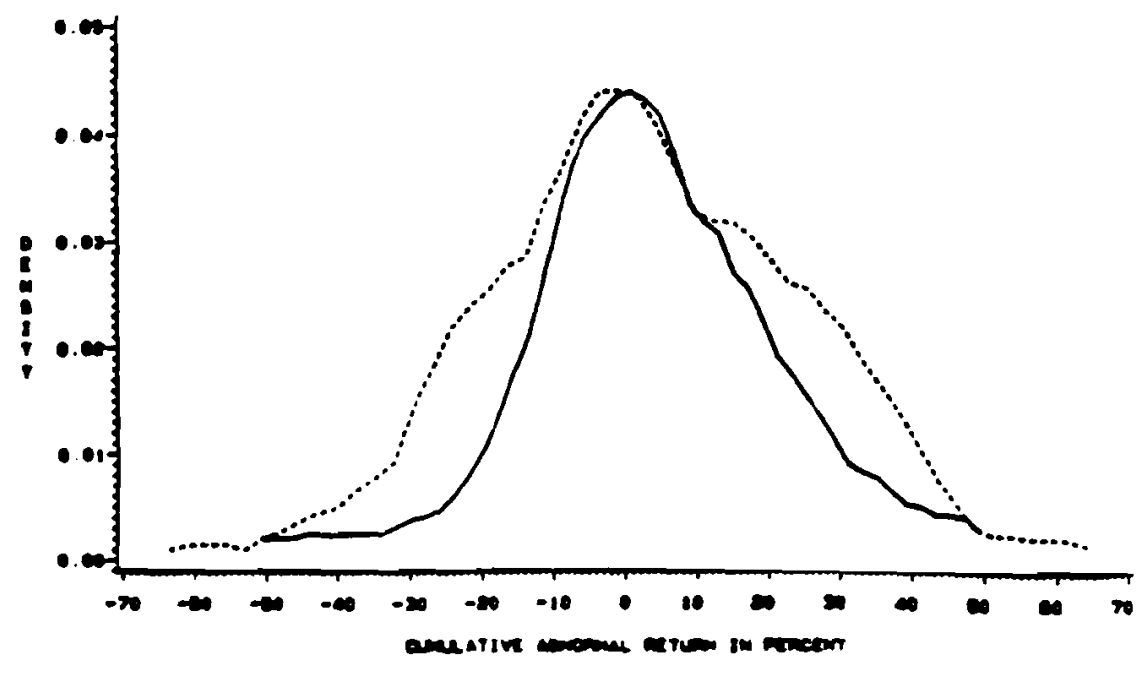


TABLE UI

Abnormal Returns in Target Firms for Various Parts of the Event Period Associated With The First

Public Announcement of Stockholding,

By The Six Investors Collectively, By A Random Sample

of Investors, and By Individual Investor

(t-statistics are given in parentheses;

sample sizes are denoted by " $N="$ ).

\begin{tabular}{|c|c|c|c|}
\hline & & Event Period & \\
\hline & $\begin{array}{l}\text { Ten Days Before } \\
\text { Through the First } \\
\text { Public Announce- } \\
\text { ment of Stockholding }\end{array}$ & $\begin{array}{l}\text { First Public } \\
\text { Announcement } \\
\text { of Stockholding }\end{array}$ & $\begin{array}{l}\text { Forty Days Befure } \\
\text { Through Forty Days } \\
\text { After the First Public } \\
\text { Announcement of } \\
\text { Stockholding }\end{array}$ \\
\hline $\begin{array}{l}\text { All Six } \\
\text { lnvestors } \\
N=99\end{array}$ & $\begin{array}{l}5.9 \% \\
(5.2)\end{array}$ & $\begin{array}{l}1.8 \% \\
(3.7)\end{array}$ & $\begin{array}{l}6.7 \% \\
(2.2)\end{array}$ \\
\hline $\begin{array}{l}\text { Random } \\
\text { Sample } \\
\quad N=155\end{array}$ & $\begin{array}{l}3.4 \% \\
(3.8)\end{array}$ & $\begin{array}{l}0.4 \% \\
(1.1)\end{array}$ & $\begin{array}{l}5.8 \% \\
(2.4)\end{array}$ \\
\hline $\begin{array}{l}\text { lcahn } \\
\qquad N=5\end{array}$ & $\begin{array}{l}7.2 \% \\
(1.5)\end{array}$ & $\begin{array}{l}2.4 \% \\
(1.2)\end{array}$ & $\begin{array}{l}21.1 \% \\
(1.6)\end{array}$ \\
\hline $\begin{array}{c}\text { Jacobs } \\
N=5\end{array}$ & $\begin{array}{l}9.6 \% \\
(1.9)\end{array}$ & $\begin{array}{l}3.8 \% \\
(1.8)\end{array}$ & $\begin{array}{l}20.6 \% \\
(1.5)\end{array}$ \\
\hline $\begin{array}{c}\text { Lindner } \\
\qquad N=21\end{array}$ & $\begin{array}{l}1.8 \% \\
(0.7)\end{array}$ & $\begin{array}{l}-1.7 \% \\
(-1.6)\end{array}$ & $\begin{array}{l}0.1 \% \\
(.02)\end{array}$ \\
\hline $\begin{array}{l}\text { Murdock } \\
\qquad \mathrm{N}=10\end{array}$ & $\begin{array}{l}9.9 \% \\
(3.7)\end{array}$ & $\begin{array}{l}3.0 \% \\
(2.7)\end{array}$ & $\begin{array}{l}12.2 \% \\
(1.7)\end{array}$ \\
\hline $\begin{array}{r}\text { Posner } \\
N=31\end{array}$ & $\begin{array}{l}7.0 \% \\
(3.8)\end{array}$ & $\begin{array}{l}3.3 \% \\
(4.2)\end{array}$ & $\begin{array}{l}3.3 \% \\
(0.7)\end{array}$ \\
\hline $\begin{array}{c}\text { Bluhdorn } \\
N=27\end{array}$ & $\begin{array}{l}4.9 \% \\
(3.1)\end{array}$ & $\begin{array}{l}1.8 \% \\
(2.7)\end{array}$ & $\begin{array}{l}7.9 \% \\
(1.9)\end{array}$ \\
\hline
\end{tabular}




\section{TABLE IV}

Abnormal Returns For Firms Filing 13(d)'s For Various

Parts of the Event Period For Both the Six Investors $(n=72)$

(1977-1982) and for the Random Sainple $(n=30)(1977-1981)$

( $t$-statistics are given in parentheses).

\begin{tabular}{lccc}
\hline & $\begin{array}{c}\text { Ten Days Before } \\
\text { Through } \\
\text { the First Public } \\
\text { Announcement of } \\
\text { Stockholding }\end{array}$ & $\begin{array}{l}\text { The First Public } \\
\text { Announcement of } \\
\text { Stockholding }\end{array}$ & $\begin{array}{l}\text { Forty Days Before } \\
\text { Through Forty Days } \\
\text { After the First Public } \\
\text { Announcement of } \\
\text { Stockholding }\end{array}$ \\
Sample & $1.9 \%$ & $1.7 \%$ & $-2.2 \%$ \\
\hline $\begin{array}{l}\text { All Six } \\
\text { Investors }\end{array}$ & $(1.4)$ & $(3.0)$ & $(-0.6)$ \\
$\begin{array}{l}\text { N=72 } \\
\text { Random }\end{array}$ & $-0.8 \%$ & $0.4 \%$ & $-2.0 \%$ \\
Sample & $(-0.6)$ & $(0.8)$ & $(-0.6)$ \\
N=30 & & & \\
\hline
\end{tabular}




\section{CUMULATIVE RETURNS FOR FILING FIRMS}

SIX INVESTORS AND RANDOM SAMPLE

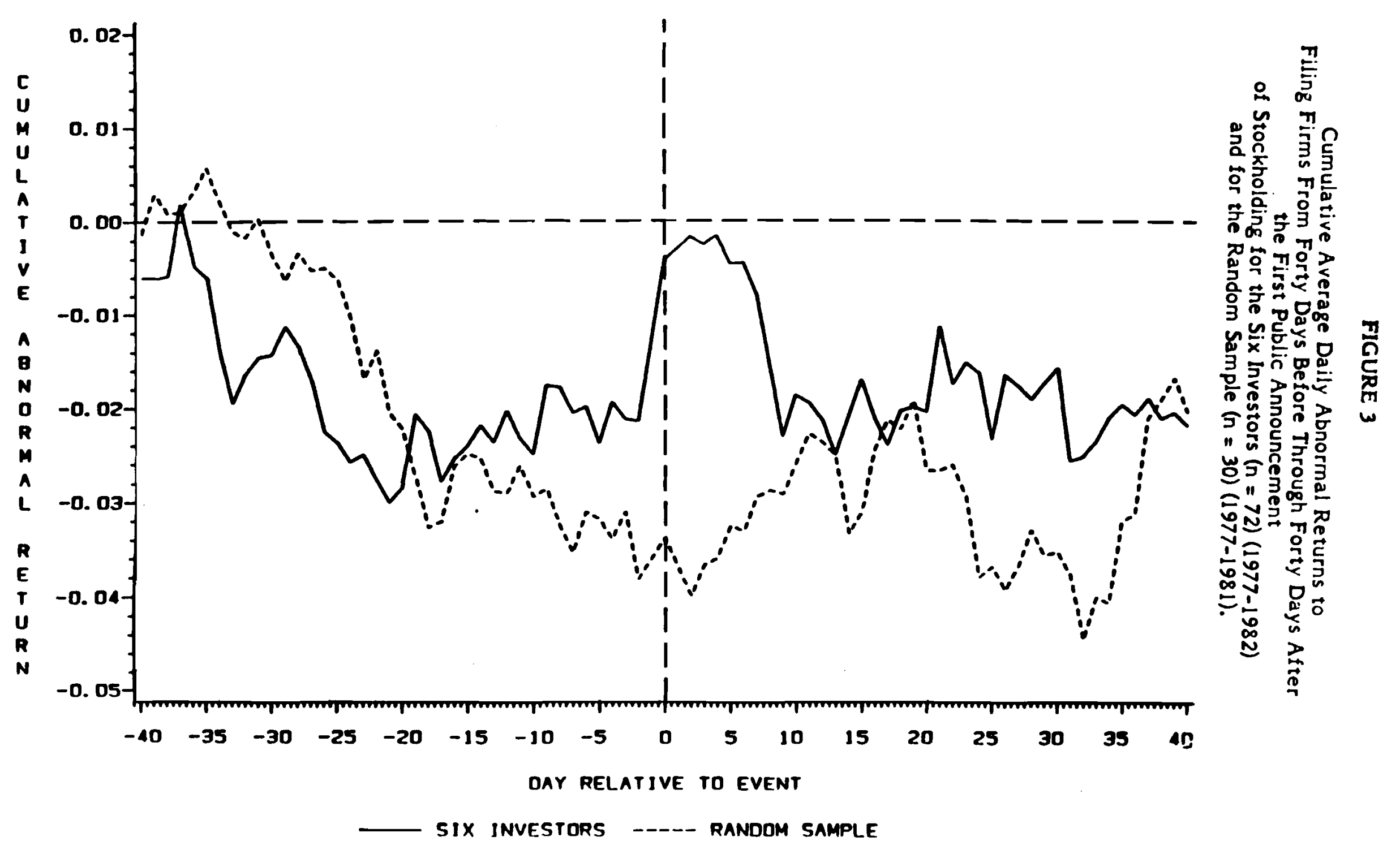




\section{TABLE V}

Summary of Activities By The Six Investors

In Target Firms For the Two Years

After the Filing of a 13(d). 1977-1982.

\begin{tabular}{|c|c|c|c|c|c|c|c|}
\hline $\begin{array}{l}\text { Number of } \\
\text { Target Firms } \\
\text { Followed For } \\
\text { Two Years After } \\
\text { Initial 13(d) }\end{array}$ & 3 & 4 & 16 & 9 & 26 & 15 & 73 \\
\hline $\begin{array}{l}\text { Number of } \\
\text { Target Firms } \\
\text { Repurchasing } \\
\text { Investor's Shares }\end{array}$ & 2 & 2 & - & 1 & 3 & 4 & 12 \\
\hline $\begin{array}{l}\text { Reorganization of } \\
\text { Target Firma/ } \\
\text { Number of Attempted } \\
\text { Reorganizations By Investor }\end{array}$ & - & 2 & 1 & 2 & - & 1 & 6 \\
\hline $\begin{array}{l}\text { Number } \\
\text { Completed }\end{array}$ & - & - & - & 2 & - & 1 & 3 \\
\hline $\begin{array}{l}\text { Number of Attempted } \\
\text { Reorganizations By Third Party }\end{array}$ & 1 & - & 4 & - & 5 & 2 & 13 \\
\hline $\begin{array}{l}\text { Number } \\
\text { Completed }\end{array}$ & 1 & - & 4 & - & 3 & 2 & 10 \\
\hline $\begin{array}{l}\text { Number of } \\
\text { News Reports of } \\
\text { Investor Involvement in } \\
\text { Management of In Target } \\
\text { Firm }\end{array}$ & 2 & 0 & 3 & 3 & 2 & 0 & 10 \\
\hline $\begin{array}{l}\text { Number of } \\
\text { Target Firms Where } \\
\text { Amended } 13(\mathrm{~d}) \text { 's } \\
\text { Were Filed }\end{array}$ & 3 & 0 & 11 & 6 & 18 & 12 & 50 \\
\hline $\begin{array}{l}\text { Average Number of } \\
\text { Amended } 13(d) \text { 's } \\
\text { Per Target Firm } \\
\text { Followed }\end{array}$ & 3.6 & 0 & 2.1 & 1.8 & 3.3 & 5.2 & 2.7 \\
\hline $\begin{array}{l}\text { Number of Firms } \\
\text { Where No } \\
\text { Indication of } \\
\text { Any Activity } \\
\text { After Initial } 13(d) \text { b/ }\end{array}$ & 0 & 1 & 3 & 0 & 5 & 1 & 9 \\
\hline
\end{tabular}

a/Reorganizations are defined in this paper to include mergers, tender offers, and going private transactions.

b/ This means that for a target firm there were no repurchases of the investors' shares, no attempts to reorganize, no news reports of management by the investor, and no amended $13(d)$ 's filed. 


\section{TABLE VI}

Average Event Day Abnormal Returns for Initial, Intermediate, and Fina! Announcements Grouped by Category of Outcome, for Target Firms of the Six Investors

( $t$-statistics in parentheses)

\begin{tabular}{|c|c|c|c|c|}
\hline $\begin{array}{l}\text { Type of Public } \\
\text { Announcements }\end{array}$ & $\begin{array}{l}\text { Successful } \\
\text { Reorganization } \\
\qquad \begin{array}{l}N=13\end{array}\end{array}$ & $\begin{array}{l}\text { Unsuccessful } \\
\text { Reorganization } \\
\qquad \begin{array}{l}N=5 \\
\text { nation }\end{array}\end{array}$ & $\begin{array}{l}\text { Repurchase } \\
\qquad \begin{array}{l}N=12\end{array}\end{array}$ & $\begin{array}{l}\text { Other } \\
N=39\end{array}$ \\
\hline $\begin{array}{l}\text { Initial Stock } \\
\text { Purchase }\end{array}$ & $\begin{array}{l}-0.3 \% \\
(-0.2)\end{array}$ & $\begin{array}{l}0.5 \% \\
(0.3)\end{array}$ & $\begin{array}{l}4.1 \% \\
(3.0)\end{array}$ & $\begin{array}{l}1.8 \% \\
(2.8)\end{array}$ \\
\hline $\begin{array}{l}\text { Intermediate } \\
\text { Events }\end{array}$ & $\begin{array}{l}15.8 \% \\
(3.5)\end{array}$ & $\begin{array}{l}12.8 \% \\
(3.7)\end{array}$ & $\begin{array}{l}-0.4 \% \\
(0.1)\end{array}$ & \\
\hline $\begin{array}{l}\text { Final } \\
\text { Event }\end{array}$ & $\begin{array}{l}-1.2 \% \\
(-0.7)\end{array}$ & $\begin{array}{l}-3.4 \% \\
(-1.9)\end{array}$ & $\begin{array}{l}-1.3 \% \\
(-1.5)\end{array}$ & \\
\hline TOTAL RETURNS & $\begin{array}{l}13.0 \% \\
(3.1)\end{array}$ & $\begin{array}{l}4.1 \% \\
(1.0)\end{array}$ & $\begin{array}{l}3.2 \% \\
(1.8)\end{array}$ & \\
\hline
\end{tabular}


L 